\title{
EFFECT OF FEEDING MORINGA OLIEFERA STEMS ON PRODUCTIVE PERFORMANCE OF LACTATING FRIESIAN COWS
}

\author{
Ghada S. El-Esawy ${ }^{1}$; W.A. Riad ${ }^{1}$; M.F.E. Ali ${ }^{2}$ and H.M.A. Gaafar ${ }^{1}$ \\ ${ }^{1}$ Animal Production Research Institute, Agriculture Research Center, Dokki, Giza, Egypt. \\ 2 Animal Production Department, Faculty of Agriculture, Kafr El-Sheikh University, Egypt.
}

(Received 27/8/2017, accepted 10/10/201 7)

\section{SUMMARY}

\begin{abstract}
$\mathrm{T}$ This study was carried out to investigate the effect of partial replacement of berseem hay by Moringa oliefera stems. Fifteen of lactating Friesian cows with average live body weight of 500 $\mathrm{kg}$ and 2-4 seasons of lactation after the peak milk yield were divided into three groups (5 each) assigned randomly to three experimental rations. Control ration (R1) consisted of $40 \%$ concentrate feed mixture $(\mathrm{CFM})+20 \%$ corn silage $(\mathrm{CS})+20 \%$ rice straw $(\mathrm{RS})+20 \%$ barseem hay $(\mathrm{BH})$, While the other rations contained 10 and 20\% Moringa oliefera stems (MS) instead of 50 and $100 \%$ of BH in R2 and R3, respectively. Results revealed that the contents of $\mathrm{CP}, \mathrm{CF}$ and ash tended to increase, however the contents of DM, OM, EE and NFE tended to decrease with increasing the level of Moringa oliefera stems in the rations. Ration 2 recorded significantly $(\mathrm{P}<00.05)$ the highest digestibility coefficients of DM, OM and CP and R3 the highest EE digestibility and DCP value. Average daily feed intake and rumen fermentation activity were nearly similar for the different groups. Total protein, albumin and globulin concentrations increased significantly $(\mathrm{P}<0.05)$, however urea-N and creatinine concentrations in plasma decreased significantly $(\mathrm{P}<0.05)$ with increasing the level of Moringa stems in the rations. Average daily yield of actual milk and $4 \%$ FCM as well as the percentages of fat, protein, total solids and solids not fat in milk increased insignificantly $(\mathrm{P}<0.05)$ with increasing the level of Moringa stems in the rations. Moringa Stems led to significant decrease $(\mathrm{P}<0.05)$ in the amounts of DM and TDN per $1 \mathrm{~kg} 4 \%$ FCM. Also, Moringa stems reduced the average daily feed cost and feed cost per one $\mathrm{kg} 4 \%$ FCM, but increased the price of $4 \%$ FCM yield and subsequently economic efficiency.
\end{abstract}

Keywords: Moringa oliefera stems, lactating Friesian cows, digestibility, milk yield and composition, feed and economic efficiency.

\section{INTRODUCTION}

In Egypt, there is a great developing gap between demand and available resources of animal milk and protein. Currently, great attention has been given to Moringa forage by many Egyptian animal nutritionists to overcome the green fodder shortage particularly during summer season. Moringa leaves had good quality protein rich of essential amino acids which can enhance dietary $\mathrm{N}$ utilization and improve animal productivity as well as Moringa forage is rich in most nutrients (Mendieta-Araica el al., 2013 and Nouman et al., 2013). Moringa leaves have been reported to be a valuable source of both macro and micro nutrients, being a significant source of beta-carotene, vitamin $\mathrm{C}$, protein, calcium, iron, and potassium (Anwar et al., 2007; Pullakhandam and Failla, 2007; Siddhuraju and Becker, 2003 and Thurber et al., 2009).

Moringa oleifera Lam (synonym: Moringa oleifera pterygosperma, Gaertner), is commonly referred to as 'drumstick tree' describing the shape of its pod or 'horseradish tree' describing the taste of the roots (Makkar and Becker, 1996). The leaves could be harvested twice a month and have diverse uses among the local people. Leaves are used as a cabbage, to treat malaria, hypertension, stomach disorders, to expel retained placenta, to treat asthma and diabetes and has antitrypanosomal activity (Mekonnen et al., 1999). It can also be used as a protein meal (crude protein approx. 60\%) in livestock diet. The leaves of this tree are also edible and are highly nutritious. It used as livestock feed; Moringa oleifera leaves (crude protein approx. 25\%). Leafs are free from anti-nutritive factors (e.g. phenols, tannins, saponins, 
etc.) and high in iron (up to $582 \mathrm{mg} / \mathrm{kg} \mathrm{DM}$ ), in beta-carotene (up to $400 \mathrm{mg} / \mathrm{kg} \mathrm{DM}$ ) and in vitamin C (up to $9.2 \mathrm{~g} / \mathrm{kg} \mathrm{DM}$ ). Lately, this plant has received a lot of attention. Moringa oleifera foliage has been found to increase animal productivity (Foidl et al. 2001). Moringa oleifera stems are suitable for feeding sheep and can be used to replace a part of $\mathrm{CH}$ or CFM without any adverse effect on the performance of Rahmani lambs (Mahmoud, 2013).

Many researchers are attention of using Moringa oleifera leaves as animal feed but it's still highly expensive in our country and we can used plant stems in ruminants diets and study the potentiality of its as animal feed. So, the objective of this study was to evaluate the effect of feeding of Moringa oleifera stems to lactating Friesian cows on intake, digestibility, rumen and blood parameters, milk yield and composition, feed conversion ratio and economic efficiency.

\section{MATERIALS AND METHODS}

The present work was carried out at Sakha Animal Production Research Station, belonging to Animal Production Research Institute (APRI), Agricultural Research Center, Ministry of Agriculture in Cooperation with Department of Animal Production, Faculty of Agriculture, Kafr El-Sheikh University, Egypt.

\section{Experimental animals and rations:}

Fifteen of lactating Friesian cows with average live body weight of $500 \mathrm{~kg}$ and 2-4 seasons of lactation after the peak milk yield were divided into three groups ( 5 each) assigned randomly to three experimental rations. Control ration (R1) consisted of $40 \%$ concentrate feed mixture (CFM) $+20 \%$ corn silage $(\mathrm{CS})+20 \%$ rice straw $(\mathrm{RS})+20 \%$ berseem hay $(\mathrm{BH})$, While the other rations contained 10 and $20 \%$ Moringa oliefera stems (MS) instead of 50 and 100\% of BH in R2 and R3, respectively.

\section{Management procedure:}

Animals were fed to cover them recommend requirements according to NRC (2001) feeding allowances for dairy cows and adjusted every week based on the average body weight of animals and milk production. Concentrate feed mixture were offered twice daily at 8 a.m. and 4 p.m. Corn silage, berseam hay and Moringa oliefera stems were offered daily at 9 a.m., while rice straw was offered adlibitumat 11 a.m. Fresh water was available continuously.

\section{Digestibility trial:}

Digestibility trail were conducted during the feeding period using 3 cows from each group to determine the digestibility and nutritive values of the experimental rations. Each digestibility trial consisted of 15 days as preliminary period followed by 7 days as collection period. Acid insoluble ash was used as a natural marker (Van keulen and Young, 1997). Feces samples were taken from the rectum of each cow twice daily with 12 hrs interval during the collection period. Samples of feedstuffs were taken at the beginning, middle and end of the period. Chemical analysis of samples of CFM, corn silage, berseem hay, rice straw and Moringa oliefera stems as well as feces samples were carried out according to the methods of AOAC (1990). Nutrient digestibility was calculated from the equation stated by Schneider and Flat (1975) as follows:

DM digestibility $\%=100-\left(\frac{\text { AIA } \% \text { in feed }}{\text { AIA } \% \text { in feces }} \times 100\right)$

Nutrient digestibility $\%=100-\left(100 \times\left(\frac{\text { AIA } \% \text { in feed }}{\text { AIA } \% \text { in feces }} \times \frac{\text { Nutrient } \% \text { in feces }}{\text { Nutrient } \% \text { in feed }}\right)\right.$

Where AIA is acid insoluble ash.

\section{Milk yield and composition:}

Cows were mechanically milked and daily milk yield was recorded individually and corrected for $4 \%$ fat corrected milk (FCM) using the formula of Gains (1928) as follows: $4 \%$ FCM $=0.4 *$ milk yield (kg) $+15^{*}$ fat yield $(\mathrm{kg})$ 
Milk samples from consecutive evening and morning milking were taken every week during the experimental period and mixed in proportion to milk yield. Composite milk samples were analyzed for fat, protein, lactose, solids not fat (SNF) and total solids (TS) using Milkoscan, model 133 B. Ash was determined by the difference.

\section{Rumen liquor samples:}

Rumen liquor samples were taken from cows at $3 \mathrm{hr}$. after the morning feeding using stomach tube with draw pulse power of the automatic milking machine. Every sample was strained through four layers of cheese cloth and rumen $\mathrm{pH}$ was determined immediately after straining the samples using Orian 680 digital $\mathrm{PH}$ meter. Ammonia nitrogen $\left(\mathrm{NH}_{3}-\mathrm{N}\right)$ was determined using saturated solution of magnesium oxide distillation according to the method of AOAC (1990). Total volatile fatty acids (TVFA's) was determined by the steam distillation method described by (Warner, 1964).

\section{Blood samples:}

Blood samples were taken from the jugular vein of cows at $3 \mathrm{hrs}$ after the morning feeding in centrifuge tubes containing anticoagulant (EDTA). Then centrifuged for 15 minutes at 4000 rotations per minute to obtain plasma and kept in deep freezer until analysis. Blood plasma protein, albumin, globulin (by difference), urea nitrogen, AST and ALT were determined calorimetrically using commercial diagnostic kits (test- Combination-Pasteur lap).

\section{Feed conversion:}

The feed conversion was expressed as the amounts of DM, TDN and DCP required for producing $1 \mathrm{~kg}$ $4 \% \mathrm{FCM}$.

\section{Economic efficiency:}

Economic parameters expressed as average daily feed cost, feed cost per one $\mathrm{kg} 4 \%$ FCM and price of $4 \%$ FCM yield were calculated. Also, economic efficiency as the ratio between the price of $4 \%$ FCM yield and average daily feed cost was calculated.

\section{Statistical analysis:}

The data were statistically analyzed using general linear model procedure adopted by IBM SPSS Statistics 22 (2014) for user's guide with one-way ANOVA. Also, Duncan test within program of SPSS was done to determine the degree of significance among the means.

\section{RESULTS AND DISCUSSIONS}

\section{Chemical composition:}

The proximate composition of feedstuffs and experimental rations are presented in Table (1). Obtained results indicated that the contents of $\mathrm{CP}, \mathrm{CF}$ and ash were higher, however the contents of DM, $\mathrm{OM}, \mathrm{EE}$ and NFE were lower in Moringa oliefera stems compared with berseem hay. So, the contents of $\mathrm{CP}, \mathrm{CF}$ and ash tended to increase, however the contents of DM, OM, EE and NFE tended to decrease with increasing the level of Moringa oliefera stems and decreasing the level of berseem hay in the rations. Such results were mainly a reflection of the chemical composition and the proportion of the experimental feedstuffs. Similar results obtained by Mahmoud (2013) who found that Moringa oleifera stems (MS) contained high protein, ash, CF and low OM, EE and NFE contents compared to clover hay (CH).

\section{Nutrients digestibility and nutritive values:}

Nutrients digestibility coefficients and nutritive values for different rations are shown in Table (2). The ration contained 10\% Moringa oliefera stems (R2) recorded significantly $(\mathrm{P}<00.05)$ the highest digestibility coefficients of DM, OM and $\mathrm{CP}$. While, the highest EE digestibility and DCP value detected significantly $(\mathrm{P}<0.05)$ with R3 $(20 \% \mathrm{MS})$. Where, the digestibility coefficients of CF and NFE as well as TDN value were insignificantly different among the three tested rations. The DCP value of R2 and R3 increased by 7.21 and $7.65 \%$ compared with R1, respectively. The better digestibility in cows with Moringa Stems additive may be a subsequence of antimicrobial and antioxidant effects of Moringa oleifera were discussed by some researchers. In general, the higher digestibility values of most nutrients 
obtained of all tested rations may be attributed to the effect of feeding such high quality roughages (CS, $\mathrm{BH}$ and MS) which provided stimulatory factors to rumen cellulolytic and other bacteria. These factors resulted in some changes in digestive function which led to increasing the availability and utilization of nutrients in the rumen and could have a significant impact on digestion and nutritive values of experimental rations. Jabeen et al. (2008) mentioned that the antimicrobial properties of the Moringa oleifera seed extracts may be due to lipophilic compounds. These compounds may attach to the cytoplasmic membrane. Talha (2013) also suggested that extracts of Moringa oleifera seeds may contain antibiotic metabolites, such as carboxylic acid, 2,4-diacetyl phloroglucinol, and cell wall-degrading enzymes and chitinases. The antioxidant effect of Moringa oleifera leaf extract and fruit was explained by Luqman et al. (2012), who noticed that it was due to the presence of polyphenols, tannins, anthocyanin, glycosides, and thiocarbamates, which remove free radicals, activate antioxidant enzymes, and inhibit oxidases.

Table (1): Chemical composition of feedstuffs and experimental rations.

\begin{tabular}{lccccccc}
\hline \multirow{2}{*}{ Item } & \multirow{2}{*}{ DM \% } & \multicolumn{7}{c}{ Composition of DM \% } \\
\cline { 3 - 8 } & & OM & CP & CF & EE & NFE & Ash \\
\hline Feedstuffs: & & & & & & & \\
Concentrate feed mixture & 89.88 & 92.51 & 16.71 & 11.32 & 2.37 & 62.11 & 7.49 \\
Berseem hay & 91.21 & 90.10 & 12.39 & 28.49 & 3.10 & 46.12 & 9.90 \\
Corn silage & 30.12 & 94.95 & 9.85 & 19.91 & 2.47 & 62.72 & 5.05 \\
Rice straw & 89.79 & 83.51 & 3.62 & 33.47 & 1.92 & 44.50 & 16.49 \\
Moringa oliefera stems & 90.22 & 88.52 & 14.50 & 33.63 & 2.48 & 37.91 & 11.48 \\
\hline Experimental rations: & & & & & & & \\
R1 (Control) & 64.45 & 90.72 & 11.86 & 20.90 & 2.45 & 55.51 & 9.28 \\
R2 (10\% MS) & 64.40 & 90.56 & 12.07 & 21.42 & 2.38 & 54.69 & 9.44 \\
R3 (20\% MS) & 64.38 & 90.40 & 12.28 & 21.93 & 2.32 & 53.87 & 9.60 \\
\hline
\end{tabular}

Table (2): Nutrients digestibility coefficients and nutritive values for different rations.

\begin{tabular}{lcccc}
\hline \multirow{2}{*}{ Item } & \multicolumn{3}{c}{ Experimental group } & \multirow{2}{*}{ SEM } \\
\cline { 2 - 4 } & $\mathrm{R} 1$ & $\mathrm{R} 2$ & $\mathrm{R} 3$ & 0.61 \\
Digestibility coefficients \% & & & & \\
DM & $66.65^{\mathrm{b}}$ & $70.13^{\mathrm{a}}$ & $69.73^{\mathrm{a}}$ & 0.71 \\
OM & $68.9^{\mathrm{b}}$ & $72.46^{\mathrm{a}}$ & $72.03^{\mathrm{ab}}$ & 0.71 \\
CP & $77.16^{\mathrm{b}}$ & $81.24^{\mathrm{a}}$ & $80.18^{\mathrm{ab}}$ & 0.54 \\
EE & $67.48^{\mathrm{ab}}$ & $66.00^{\mathrm{b}}$ & $68.42^{\mathrm{a}}$ & 1.33 \\
CF & 67.47 & 66.76 & 67.22 & 0.79 \\
NFE & 67.34 & 69.02 & 67.99 & 0.79 \\
Nutritive values \% & & & 64.79 & 0.15 \\
TDN & 64.35 & 65.38 & $9.85^{\mathrm{a}}$ & \\
DCP & $9.15^{\mathrm{b}}$ & $9.81^{\mathrm{a}}$ & & \\
\hline
\end{tabular}

$a, b$ : Values in the same row with different superscripts differ significantly $(P<0.05)$.

$R 1=$ Control ration $($ consisted of $40 \%$ concentrate feed mixture $(C F M)+20 \%$ corn silage $+20 \%$ rice straw $+20 \%$ berseem hay),

$R 2=$ Control ration $+10 \%$ Moringa oliefera stems $+50 \%$ berseem hay,

$R 3=$ Control ration $+20 \%$ Moringa oliefera stems $+100 \%$ berseem hay.

\section{Feed intake:}

Average daily feed intake for the different groups is presented in Table (3). There were no significant differences $(\mathrm{P}<0.05)$ in average daily feed intake among the different groups. Total DM intake tended to increase with R2, while TDN, CP and DCP intake tended to increase with R2 and R3. The increases in TDN, CP and DCP intake for R2 and R3 is probably a reflection of increasing quality of the diets with increasing level of Moringa which well be probably enhance the utilization and the availability of essential nutrients especially protein, energy and mineral of the dietary organic matter. These results agreed with those obtained by Mahmoud (2013) who indicated that feed intake by lambs was nearly similar with the same ratio of roughage concentrate as well as with the same ratio of clover hay and moringa stems. 
Egyptian J. Nutrition and Feeds (2018)

Table (3): Average daily feed intake (kg/head/day) for different groups.

\begin{tabular}{|c|c|c|c|c|}
\hline \multirow{2}{*}{ Item } & \multicolumn{3}{|c|}{ Experimental group } & \multirow{2}{*}{ SEM } \\
\hline & $\mathrm{R} 1$ & $\mathrm{R} 2$ & R3 & \\
\hline Concentrate feed mixture* & 7.08 & 7.17 & 7.07 & \\
\hline Berseem hay & 3.49 & 1.77 & - & \\
\hline Corn silage* & 10.56 & 10.69 & 10.55 & \\
\hline Rice straw* & 3.54 & 3.59 & 3.54 & \\
\hline Moringa oliefera stems* & - & 1.78 & 3.52 & \\
\hline Total DM & 15.90 & 16.10 & 15.89 & 0.27 \\
\hline TDN & 10.23 & 10.53 & 10.30 & 0.15 \\
\hline $\mathrm{CP}$ & 1.89 & 1.94 & 1.95 & 0.07 \\
\hline DCP & 1.45 & 1.58 & 1.57 & 0.04 \\
\hline
\end{tabular}

\section{Rumen fermentation activity:}

Rumen fermentation activity is shown in Table (4). Rumen liquor parameters did not significantly $(\mathrm{P}>0.05)$ alter with replacing berseem hay by Moringa stems. Ruminal $\mathrm{pH}$ value and the concentrations of TVFA's and $\mathrm{NH}_{3}-\mathrm{N}$ were nearly similar for the different groups being 6.24-6.36, 6.33-6.82 meq/100 $\mathrm{ml}$ and $24.25-25.01 \mathrm{mg} / 100 \mathrm{ml}$, respectively. The means of $\mathrm{pH}$ values of sheep fed the different rations were within the normal range as mentioned by Hungate (1996) being 5.5 to 6.85. Mahmoud (2013) indicated that inclusion of MS in tested rations had created similar rumen environment in relation to TVFA's production which showed closer values for all dietary rations either before or after feeding. Ammonia-N concentration was within the normal range described by Church (1976), being 10 to 45 $\mathrm{mg} / 100 \mathrm{ml}$ depending on composition of the ration, time of sampling and method of analysis used.

Table (4): Rumen fermentation activity for different groups.

\begin{tabular}{lcccc}
\hline \multirow{2}{*}{ Item } & \multicolumn{3}{c}{ Experimental group } & \multirow{2}{*}{ SEM } \\
\cline { 2 - 4 } & $\mathrm{R} 1$ & $\mathrm{R} 2$ & $\mathrm{R} 3$ & 0.17 \\
\hline $\mathrm{pH}$ value & 6.36 & 6.24 & 6.26 & 0.28 \\
TVFA's (meq/100 ml) & 6.33 & 6.38 & 6.82 & 1.45 \\
$\mathrm{NH}_{3}$-N (mg/100 ml) & 24.86 & 25.01 & 24.25 &
\end{tabular}

$R 1=$ Control ration (consisted of $40 \%$ concentrate feed mixture $(C F M)+20 \%$ corn silage $+20 \%$ rice straw $+20 \%$ berseem hay),

$R 2=$ Control ration $+10 \%$ Moringa oliefera stems $+50 \%$ berseem hay,

$R 3=$ Control ration $+20 \%$ Moringa oliefera stems $+100 \%$ berseem hay

\section{Blood biochemical:}

Results of some blood parameters are shown in Table (5). Total protein, albumin and globulin concentrations in blood plasma increased significantly $(\mathrm{P}<0.05)$, however urea- $\mathrm{N}$ and creatinine concentrations in plasma decreased significantly $(\mathrm{P}<0.05)$ with increasing the level of Moringa stems and decreasing the level of berseem hay. While, liver AST and ALT enzymes activity was nearly similar for the different groups. Plasma total protein was within the normal range being 6-8 g/dl (Kancko, 1989). Blood plasma transaminase enzymes activity (ALT and AST) are the most important indicators of liver cells activity where increasing the concentration of these enzymes indicate the tissue activity are destroyed (Molander et al., 1957). According to Maxwell et al. (1990), blood parameters are important in assessing the quality and suitability of feed ingredients in farm animals. Animashahun et al. (2006) affirmed that the comparison of blood chemistry profile with nutrient intake might indicate the need for adjustment of certain nutrients upward or downward for different population groups. Evaluation of the 
blood profile of animals may give some insight as to the potentials of a dietary treatment to meet the metabolic needs of the animal since according to Church et al. (1984), dietary components have measurable effects on blood constituents such that significant changes in their values can be used to draw inference on the nutritive value of feeds offered to the animals.

Table (5): Blood plasma biochemical for different groups.

\begin{tabular}{lcccc}
\hline \multirow{2}{*}{ Item } & \multicolumn{3}{c}{ Experimental group } & SEM \\
\cline { 2 - 4 } & $\mathrm{R} 1$ & $\mathrm{R} 2$ & $\mathrm{R} 3$ & 0.28 \\
\hline Total protein $(\mathrm{g} / \mathrm{dl})$ & $7.10^{\mathrm{b}}$ & $7.62^{\mathrm{ab}}$ & $7.96^{\mathrm{a}}$ & 0.17 \\
Albumin (g/dl) & $3.68^{\mathrm{b}}$ & $4.06^{\mathrm{ab}}$ & $4.32^{\mathrm{a}}$ & 0.24 \\
Globulin (g/dl) & $3.42^{\mathrm{b}}$ & $3.56^{\mathrm{ab}}$ & $3.64^{\mathrm{a}}$ & 0.83 \\
Urea-N (g/d) & $28.44^{\mathrm{a}}$ & $25.3^{\mathrm{ab}}$ & $22.92^{\mathrm{b}}$ & 0.066 \\
Creatinine (g/d) & $1.36^{\mathrm{a}}$ & $1.10^{\mathrm{ab}}$ & $1.01^{\mathrm{b}}$ & 0.53 \\
AST (U/L) & 44.42 & 43.38 & 42.24 & 0.31 \\
ALT (U/L) & 14.58 & 13.54 & 13.08 & $0.05)$. \\
\hline
\end{tabular}

$a, b$ : Values in the same row with different superscripts differ significantly $(P<0.05)$.

$R 1=$ Control ration (consisted of $40 \%$ concentrate feed mixture $(C F M)+20 \%$ corn silage $+20 \%$ rice straw $+20 \%$ berseem hay),

$R 2=$ Control ration $+10 \%$ Moringa oliefera stems $+50 \%$ berseem hay,

$R 3=$ Control ration $+20 \%$ Moringa oliefera stems $+100 \%$ berseem hay.

\section{Milk yield:}

Results of milk yield are shown in Table (6). Average daily yield of actual milk and 4\% FCM increased insignificantly $(\mathrm{P}<0.05)$ with Moringa stems. Cows fed R3 recorded the highest average daily actual milk and 4\% FCM yield followed by R2, where R1 had the lowest yield. Actual milk yield of R2 and R3 increased by 8.88 and $11.34 \%$ compared with R1, respectively. The corresponding values for $4 \%$ FCM were 10.72 and $16.49 \%$, respectively. These results view that Moringa oleifera has a positive effect on the rumen environment, leading to increased rumen microbial output or to the fact that the protein in Moringa oleifera also has good rumen bypass characteristics. These results agreed with those obtained by Reyes et al. (2006) who reported an increase $(\mathrm{P}<.0 .05)$ in milk production from 3.1 to 4.9 and 5.1 $\mathrm{kg}$ /day when Moringa oleifera was supplemented by 2 or $3 \mathrm{~kg}$ DM, respectively. Likewise, Sarwatt et al. (2004) reported that the milk yield in cross bred cows was increased $(\mathrm{P}<0.05)$ due to feeding Moringa oleifera. Reyes et al. (2006) pointed out that increase in milk yield might be due to increase CP intake. Cows supplemented with Moringa oleifera had $13 \%$ and $30 \%$ higher milk production respectively, than cows fed a basal diet of Hyparreniaruffa grass or Sorghum vulare straw (Rocha and Mendieta, 1988 and Foidl et al., 2001). Mohamed et al. (2014) found that fresh milk and 4\% FCM yields were increased $(\mathrm{P}<0.05)$ with rations contained either 20 and $40 \%$ Moringa by 16.00 and $25.40 \%$ than those fed $40 \%$ berseem ration.

\section{Milk composition:}

Milk composition in Table (8) Showed significant $(\mathrm{P}<0.05)$ differences in the contents of fat, protein, total solids and solids not fat in milk among the different groups. Which, cows fed R3 recorded significant $(\mathrm{P}<0.05)$ the highest fat, protein, total solids and solids not fat contents in milk followed by R2, where R1 had the lowest contents. However, the contents of lactose and ash tended to increase with increasing the level of Moringa stems with insignificant differences. The current results obtained are in agreement with those reported by Reyes-Sanchez et al. (2006) who described the similar findings that cows supplemented with Moringa oleifera had more milk fat and CP than cows fed brachiariabrizantha hay alone or with sorghum silage as a basal diet. 
Table (6): Average daily milk yield and composition for different groups.

\begin{tabular}{ccccc}
\hline \multirow{2}{*}{ Item } & \multicolumn{3}{c}{ Lactation period (month) } & Mean \\
\cline { 2 - 5 } Average daily milk yield (kg/day): & $\mathrm{R} 1$ & $\mathrm{R} 2$ & $\mathrm{R} 3$ & \\
Actual milk & $14.64^{\mathrm{b}}$ & $15.94^{\mathrm{ab}}$ & $16.30^{\mathrm{a}}$ & 0.34 \\
Increase\% & $0.00^{\mathrm{c}}$ & $8.88^{\mathrm{b}}$ & $11.34^{\mathrm{a}}$ & 1.72 \\
4\% F C M & $13.34^{\mathrm{b}}$ & $14.77^{\mathrm{ab}}$ & $15.54^{\mathrm{a}}$ & 0.38 \\
Increase\% & $00.00^{\mathrm{c}}$ & $10.72^{\mathrm{b}}$ & $16.49^{\mathrm{a}}$ & 2.42 \\
Milk composition \%: & & & \\
Fat & $3.41^{\mathrm{b}}$ & $3.51^{\mathrm{ab}}$ & $3.69^{\mathrm{a}}$ & 0.07 \\
Protein & $2.70^{\mathrm{b}}$ & $2.82^{\mathrm{ab}}$ & $2.88^{\mathrm{a}}$ & 0.05 \\
Lactose & 4.65 & 4.70 & 4.81 & 0.07 \\
TS & $11.45^{\mathrm{b}}$ & $11.73^{\mathrm{ab}}$ & $12.09^{\mathrm{a}}$ & 0.19 \\
SNF & $8.04^{\mathrm{b}}$ & $8.22^{\mathrm{ab}}$ & $8.40^{\mathrm{a}}$ & 0.13 \\
Ash & 0.69 & 0.70 & 0.71 & 0.01 \\
\hline
\end{tabular}

$a, b, c:$ Values in the same row with different superscripts differ significantly $(P<0.05)$.

$R 1=$ Control ration $($ consisted of $40 \%$ concentrate feed mixture $(C F M)+20 \%$ corn silage $+20 \%$ rice straw $+20 \%$ berseem hay),

$R 2=$ Control ration $+10 \%$ Moringa oliefera stems $+50 \%$ berseem hay,

$R 3=$ Control ration $+20 \%$ Moringa oliefera stems $+100 \%$ berseem hay

\section{Feed conversion ratio:}

Feed conversion ratio expressed as the amounts of DM, TDN and DCP per $1 \mathrm{~kg} 4 \%$ FCM as affected by Moringa Stems level are shown in Table (7). Moringa Stems led to significant decrease $(\mathrm{P}<0.05)$ in the amounts of DM and TDN per $1 \mathrm{~kg} 4 \%$ FCM, which decreased by 8.40, 7.79 and $14.29,14.29 \%$ for R2 and R3 compared with R1, respectively. However, the amounts of CP and DCP per $1 \mathrm{~kg} 4 \% \mathrm{FCM}$ tended to decrease with MS supplementation without significant differences among the different groups. The improvements of feed conversion ratio with Moringa Stems may be attributed to the improvements in nutrients digestibility (Table 2), feed intake (Table 3), rumen fermentation activity (Table 4) and milk yield (Table 8). These results are in accordance with those obtained by Mahmoud (2013) who reported that feed efficiency was better for lambs fed ration containing 25\% Moringa oleifera stems in replace to clover hay and concentrate feed mixture compared to the control ration due to the beneficial effects of Moringa providing stimulator factors and essential nutrients specially protein, energy, minerals and vitamins that better utilized by sheep.

Table (7): Feed conversion ratio and economic efficiency for different groups.

\begin{tabular}{lcccc}
\hline \multirow{2}{*}{ Item } & \multicolumn{3}{c}{ Experimental group } & SEM \\
\cline { 2 - 4 } Feed conversion ratio: & R1 & R2 & R3 & \\
DM, kg/kg FCM & $1.19^{\mathrm{a}}$ & $1.09^{\mathrm{ab}}$ & $1.02^{\mathrm{b}}$ & 0.04 \\
TDN, kg/kg FCM & $0.77^{\mathrm{a}}$ & $0.71^{\mathrm{ab}}$ & $0.66^{\mathrm{b}}$ & 0.02 \\
CP, kg/kg FCM & 0.14 & 0.13 & 0.13 & 0.008 \\
DCP, kg/kg FCM & 0.11 & 0.11 & 0.10 & 0.006 \\
Economic efficiency: & & & \\
Daily feed cost, LE/day & $47.55^{\mathrm{a}}$ & $46.58^{\mathrm{ab}}$ & $44.39^{\mathrm{b}}$ & 1.43 \\
Feed cost (LE)/ kg 4\% FCM & $3.56^{\mathrm{a}}$ & $3.15^{\mathrm{ab}}$ & $2.86^{\mathrm{b}}$ & 0.16 \\
Price of 4\% FCM yield, LE/day & $60.48^{\mathrm{b}}$ & $66.47^{\mathrm{a}}$ & $69.93^{\mathrm{a}}$ & 1.75 \\
Economic efficiency & $1.27^{\mathrm{b}}$ & $1.43^{\mathrm{ab}}$ & $1.58^{\mathrm{a}}$ & 0.12 \\
\hline
\end{tabular}

$a, b$ : Values in the same row with different superscripts differ significantly $(P<0.05)$.

Prices of one $\mathrm{kg}$ were $4.70 \mathrm{LE}$ for concentrate feed mixture, 2.10 LE for berseem hay, $0.50 \mathrm{LE}$ for corn silage, 0.32 LE for rice straw, 1.20 LE for moringa stems and 4.50 LE for $4 \%$ fat corrected milk according to prices 2017.

$R 1=$ Control ration (consisted of $40 \%$ concentrate feed mixture $(C F M)+20 \%$ corn silage $+20 \%$ rice straw $+20 \%$ berseem hay),

$R 2=$ Control ration $+10 \%$ Moringa oliefera stems $+50 \%$ berseem hay,

$R 3=$ Control ration $+20 \%$ Moringa oliefera stems $+100 \%$ berseem hay. 


\section{Economic efficiency:}

Data of economic efficiency presented in Table (7) showed that Moringa Stems additive resulted in significant $(\mathrm{P}<0.05)$ improvements in economic efficiency. Average daily feed cost and feed cost per $\mathrm{kg}$ $4 \%$ FCM decreased significantly $(\mathrm{P}<0.05)$, however, the price of $4 \% \mathrm{FCM}$ yield and economic efficiency increased significantly $(\mathrm{P}<0.05)$ with Moringa Stems additive. Cows fed R3 (20\% Moringa stems) recorded significantly $(\mathrm{P}<0.05)$ the best results concerning the economic efficiency followed by those fed $\mathrm{R} 2$ compared with those fed the control ration.

\section{CONCLUSION}

It could be concluded that introducing Moringa stems at the level of $20 \%$ in replacing all berseem hay in the ration of lactating cows recorded the best results concerning digestibility, blood plasma parameters, milk yield and composition, feed and economic efficiency.

\section{REFERENCES}

Anwar, F.; S. Latif; M. Ashraf and A. H. Gilani (2007). Moringa oleifera: a food plant with multiple biochemical and medicinal uses- a review. Phytother. Res., 21: 17-25.

Basitan, I. S. and G. J. Emma (2013). Yield, Quality and Feed Cost Efficiency of Milk Produced by Anglo-Nubian Goats Fed Different Mixtures of Napier (Pennistum Purpureum) Grass and Malunggay (Moringa oleifera). Philip. J. Vet. Anim. Sci., 39: 193-200.

Church. D.C. (1976). Digestive Physiology and Nutrition Ruminants, Vol. 1. Digestive Physiology 145. 2nd Ed. 8 Books, Corvallis, Oregan.

Foidl, N.; H. P. S. Makkar and K. Becker (2001). The potential of Moringa oleifera for agricultural and industrial uses. In : L. J. Fugile 9ED. The miracle tree : the multiple attributes of Moringa. CTA. Publication. Wagenhngen, The Netherlands, pp 45-76.

Gains, W. L. (1928). The energy basis of measuring milk yield in dairy cows. University of Lllinois. Agriculture Experiment Station. Bulletin No. 308

IBM SPSS Statistics 22 (2014). Statistical Package for the social sciences. Release 22, SPSS INC, Chicago, USA,

Mahmoud, A. (2013). Effect of Feeding On Moringa Oleifera Stems on Productive Performance of Growing Lambs. Egyptian J. Nutrition and Feeds (2013), 16: 281-292.

Makkar, H.P.S. and K. Becker (1996). Nutritional value and anti-nutritional components of whole and extracted Moringa oleifera leaves. Anim. Feed Sci. Technol., 63:211-228.

Maxwell, M.H.; W. Robertson; S. Spener and C.C. Maclorquodale (1990). Comparison of hematological parameters in restricted and ad libitum fed domestic fowls. British Poult. Sci., 31:407-413.

Mekonnen, Y.; V. Yardley; P. Rock and S. Croft (1999). In vitro antitrypanosomal activity of Moringa oleifera stenopetala leaves and roots. Phototherapy Research, 13:538-539.

Mendieta- Araica, B.; E. Sporndly; N. Reyes-Sanchez; Salmeron-Miranda and Halling, M. (2013). Biomass production and chemical composition of Moringaoleifera under different planting densities and level of nitrogen fertilization, Agroforestry System. 87: 81-92.

Mohamed, S. K.; A. M. Shwerab; A. A. Hassan; M. H. Yacout; Y. A. El-Badawi and M. Saed (2014). Nutritional evaluation of Moringa Oleifera fodder in comparison with Trifoliumalexandrinum (berssem) and impact of feeding on lactation performance of cows. Life Sci., J. 11: 1040-1054.

Molander, D.W.; E. Sheppard and M.A. Pyen (1957). Serum transaminase in liver disease. J. Anim. Sci., $163: 1461$. 
Nouman, W.; S. M. Basra; M. T. Siddiqui; A. Yasmeen; T. Gull and M. A. Alcayde (2013). Potential of Moringaoleifera L. as livestock fodder crop: a Review. Turk. J. Agric., doi:10.3906/tar-1211-66.

NRC (2001). Nutrient requirements of dairy cattle. National Academy Press, Washington, D.C.

Owens, F. N.; Secrits, D. S.; Hill, W. J. and Jill, D. R. (1998). Acidosis in cattle: a review. J. Anim. Sci., 76: 275 .

Pullakhandam, R. and M. L. Failla (2007). Micellarization and intestinal cell uptake of $\beta$-carotene and Lutein from Drumstick (Moringaoleifera) Leaves. J. Med and Food, 10: 252-725.

Reyes Sa'nchez, N.; B. Eva Spo“ rndly and Inger Ledin (2006). Effect of feeding different levels of foliage of Moringa oleiferato Creole dairy cows on intake, digestibility, milk production and composition. Livestock Science 101:24-31.

Reyes Sanchez, N.; E. Sporndly and I. Ledin (2006). Effect of different levels of foliage Moringa oliefera to creole dairy cows on intake, digestibility, milk production and composition.Livest.

Rocha, M.L.R. and B. Mendieta (1998). Efecto de la suplementacio nconfollaje de Moringa oleiferasobre la producción de lechedevacasenpastoreo. TesisIng. Agron. Facultad de Ciencia Animal. Universidad Nacional Agraria Nicaragua, Managua. p. 36.

Sarwatt, S. V.; S. S. Kapange and A. M. V. Kakengi (2002). Substituting sunflower seed-cake with Moringaoleiferaleaves as supplemental goat feed in Tanzania. AgroforestSyst 56: 241-247.

Talha, E. A. (2013). The use of Moringa Oleifera in poultry diets. J. Anim. Sci. 37: 492-496.

Van Keulen, J.V. and B.A.Young (1977). Evaluation of acid insoluble ash as a natural marker in ruminant digestibility studies. J. Animal. Sci., 44: 282-287.

Warner, A.C.I. (1964). Production of volatile fatty acids in the rumen, methods of measurements. Nutr.Abst. and Rev., 34:339.

\section{تأثير التغذية على سيقان المورينجا على الاداء الإنتاجي للأبقار الحلابة}

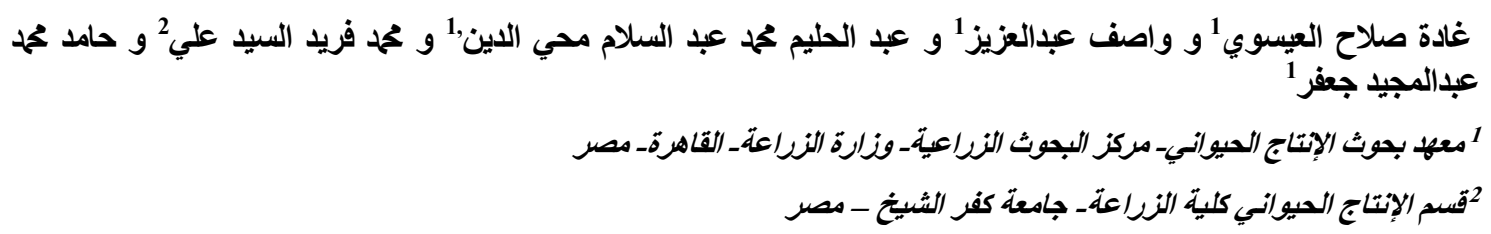

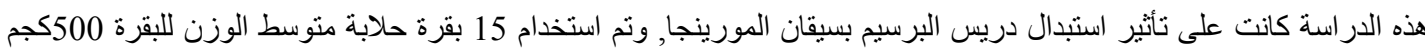

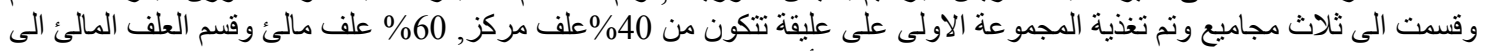

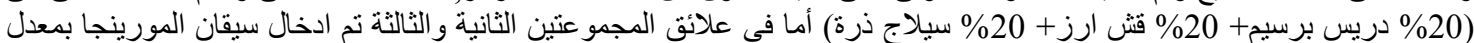

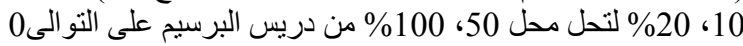

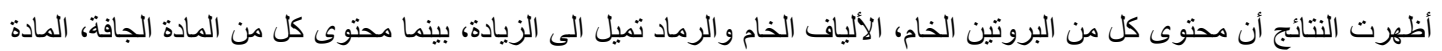

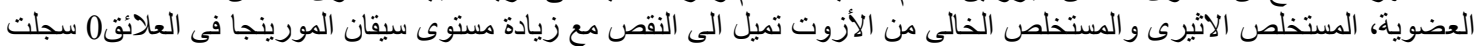

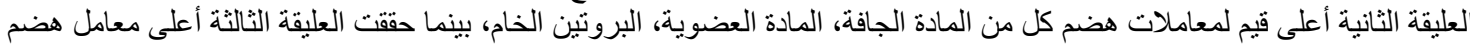

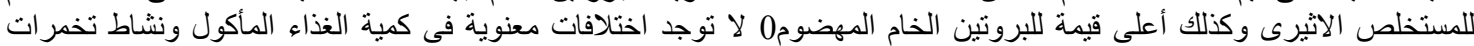

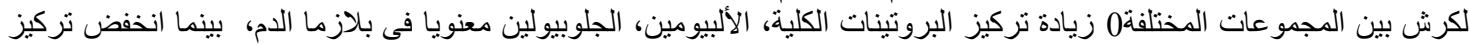

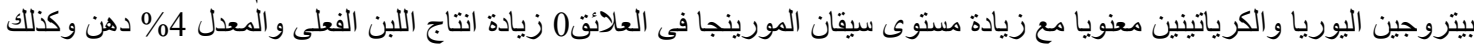

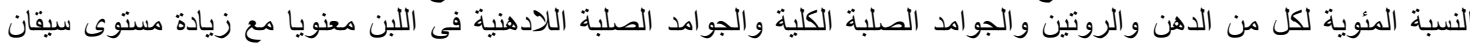

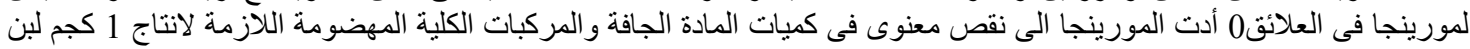
معدل 4\% دهن

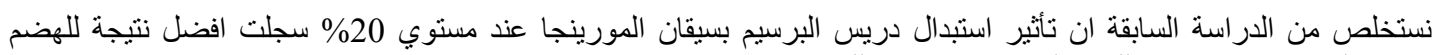
ومحتويات الدم وانتاج وتركيب اللبن و الكفاءة الاقتصادية للتغذية. 